\title{
Docetaxel Rechallenge Improves Survival in Patients With Metastatic Castration-resistant Prostate Cancer: A Retrospective Study
}

\author{
SHENG-CHUN HUNG ${ }^{1,2}$, LI-WEN CHANG $^{1,2}$, JIAN-RI LI $^{1,2,3}$, SHIAN-SHIANG WANG ${ }^{1,2,4}$, \\ CHENG-KUANG YANG ${ }^{1}$, CHUAN-SHU CHEN ${ }^{1,2}$, KEVIN LU $^{1,5}$, CHENG-CHE CHEN $^{1}$, SHU-CHI WANG ${ }^{1}$, \\ CHIA-YEN LIN ${ }^{1,2}$, CHEN-LI CHENG ${ }^{1,2}$, YEN-CHUAN OU ${ }^{1,2,6,7}$ and KUN-YUAN CHIU ${ }^{1,4}$ \\ ${ }^{1}$ Division of Urology, Department of Surgery, Taichung Veterans General Hospital, Taichung, Taiwan, R.O.C.; \\ ${ }^{2}$ Institute of Medicine, Chung Shan Medical University, Taichung, Taiwan, R.O.C.; \\ ${ }^{3}$ Department of Medicine and Nursing, Hungkuang University, Taichung, Taiwan, R.O.C.; \\ ${ }^{4}$ Department of Applied Chemistry, National Chi Nan University, Nantou, Taiwan, R.O.C.; \\ ${ }^{5}$ School of Medicine, National Yang Ming University, Taipei, Taiwan, R.O.C.; \\ ${ }^{6}$ Department of Medical Research, Taichung Veterans General Hospital, Taichung, Taiwan, R.O.C.; \\ ${ }^{7}$ Department of Urology, Tungs' Taichung MetroHarbor Hospital, Taichung, Taiwan, R.O.C.
}

\begin{abstract}
Background/Aim: Docetaxel has been widely used in metastatic Castration-resistant Prostate Cancer ( $m C R P C)$ patients for decades. The purpose of the study was to evaluate the efficacy of docetaxel rechallenge in patients with $m C R P C$. Patients and Methods: We retrospectively compared patients who had received either first-line docetaxel and rechallenge after Androgen Receptor-axis Targeted therapies (ARAT), to those without rechallenge docetaxel. Multivariate cox-regression analysis was used to evaluate survival. Results: Out of the 204 patients with $m C R P C$ enrolled in the study, 24 patients received docetaxel rechallenge and 180 did not. The median overall survival was 50.11 months in the rechallenge group, as compared to 26.36 months in the non-rechallenge group ( $p$ of log rank=0.044). In the multivariate model, doxetaxel rechallenge was an independent risk factor for overall survival [hazard ratio $(H R)=0.59,95 \%$ confidence interval $(C I)=0.32-0.99]$, together with the performance status score $2(H R=2.46,95 \% C I=1.32-4.58)$, hormone-sensitive state
\end{abstract}

This article is freely accessible online.

Correspondence to: Kun Yuan Chiu, Division of Urology, Department of Surgery, Taichung Veterans General Hospital, No. 1650, Sec. 4, Taiwan Boulevard, Taichung 40705, Taiwan, R.O.C., Tel: +886 423741215, Fax: +886 423593160, e-mail: chiu37782002@yahoo.com

Key Words: Docetaxel rechallenge, metastatic-castration resistant prostate cancer, overall survival. duration $(H R=0.99,95 \% C I=0.99-0.999)$, liver $(H R=1.90$, 95\%CI=1.04-3.47) and brain metastases (HR=2.23, 95\%CI=1.26-5.46). The advantage of rechallenge was addressed in the androgen receptor-axis-targeted (ARAT) non-responsive patients $(H R=0.36,95 \% C I=0.17-0.78)$. Adverse events were at $29.17 \%$ with Grade 3/4 neutropenia and at $20.83 \%$ with Grade 1/2 neutropenia in the docetaxel rechallenge group. Conclusion: The docetaxel rechallenge improved survival in patients with $m C R P C$ failure of firstline docetaxel and subsequent abiraterone acetate or enzalutamide. Independent predictive factors for overall survival included $i)$ the performance status, ii) hormonesensitive state duration, iii) liver and iv) brain metastases. Patients non-responsive to ARATs will benefit from docetaxel rechallenge with regards to overall survival.

Chemotherapy with docetaxel was approved for its efficacy in metastatic Castration-resistant Prostate Cancer (mCRPC) by two randomized-control phase III trials (SWOG 99-16 study and TAX-327 study) in 2004, which demonstrated its advantage in prolonged overall survival and symptom control $(1,2)$. A combination of docetaxel and castration therapy had been the standard treatment for mCRPC for a decade until the emergence of two Androgen Receptor Axis Targeted agents (ARATs), i) Abiraterone acetate, a potent inhibitor of cytochrome P450 c17 in androgren biosynthesis, and ii) Enzalutamide, an inhibitor of nuclear translocation of the androgen receptor, which have both demonstrated the efficacy and survival improvement in a large-scale clinical trial (3-6). Despite this, there is still a lack of solid evidence surrounding the best treatment 
sequence for mCRPC. Docetaxel rechallenge appears to preserve efficacy after the progression of tumor and has, therefore, been proposed as a treatment option $(7,8)$.

The concept of docetaxel rechallenge, previously described as the re-administration of docetaxel upon progression after a predefined number of sequential docetaxel cycles, involves preserved anti-tumor activity and good tolerability in a selected population $(7,8)$. In clinical practice, most patients diagnosed with $\mathrm{mCRPC}$ receive docetaxel as the first line of treatment, and subsequently turn to ARATs as the second line treatment after disease progression, according to the previous treatment guidelines $(3,5)$. The role of docetaxel rechallenge in the era of ARATs remains unclear; however, a retrospective cohort study has shown its positive outcome in improving survival and symptoms when used after the failure of frontline treatment, while partial Prostate Specific Antigen (PSA) response at rechallenge sequence and a treatment-free interval of $>3$ months has been associated with improved survival (9).

The aim of our study was to investigate the feasibility and tolerability of docetaxel rechallenge and to better understand the clinical factors that indicate a positive treatment response and an improved survival.

\section{Patients and Methods}

This is a retrospective chart-review study, where patients diagnosed with mCRPC at Taichung Veterans General Hospital from 2008 to 2016 were enrolled. Two hundred and four patients included in this study received informed consent forms prior to treatment, according to the certifications of the Institute Review Board of Taichung Veterans General Hospital (No CE20173B). Patients with mCRPC who met the criteria of: i) pathology confirmed prostate adenocarcinoma and ii) progression following castration (testosterone level $<50 \mathrm{ng} / \mathrm{dl}$ ) were enrolled. Twenty-four patients were in docetaxel rechallenge group and 180 patients in the non-rechallenge group.

Androgen deprivation therapy was used on metastasis prostate cancer and across the whole period of MCRPC and included i) surgical castration (orchiectomy) or ii) medical castration, involving LH-RH agonists or antagonists. The use of chemotherapy with docetaxel was defined as $75 \mathrm{mg} / \mathrm{m}^{2}$ during a 3 -week interval, in combination with $10 \mathrm{mg}$ prednisone daily, while $50 \mathrm{mg} / \mathrm{m}^{2}$ over a 2 -week interval was also introduced at our institute, which was later transferred into standard 3-week cycle counts. ARATs included $1,000 \mathrm{mg}$ abiraterone acetate (AA) with prednisolone at 5 or $10 \mathrm{mg}$ per day and Enzalutamide (ENZ) at $160 \mathrm{mg}$ per day. Chemotherapy with cabazitaxel was also used at $25 \mathrm{mg} / \mathrm{m}^{2}$ during a 3-week interval in combination with $10 \mathrm{mg}$ prednisone daily. PSA progression was defined according to the Prostate Cancer Working Group second publication (PCWG2) criteria (10).

The patients were grouped into docetaxel rechallenge and nonrechallenge groups, with characteristics, including: i) age at mCRPC, ii) Eastern Cooperative Oncology Group (ECOG) performance status, iii) PSA at initial metastatic prostate cancer, iv) nadir PSA at metastatic hormone sensitive prostate cancer (mHSPC), v) hormone-sensitive state duration (months, defined as from initial ADT to mCRPC), vi) Gleason score $(\mathrm{G} / \mathrm{S})$, vii) hypertension, viii) diabetes mellitus, ix) coronary artery disease, $\mathrm{x}$ ) body mass index (BMI, $\mathrm{kg} / \mathrm{m}^{2}$ ), and $\mathrm{xi}$ ) metastatic status (bone, lymph node, lung, liver and brain).

The metastatic status for mCRPC was also taken into consideration. High volume disease was defined as the presence of visceral metastases of 4 or more bone lesions, with more than 1 lesion located beyond the vertebral bodies and pelvis when compared to low volume disease (11). High-risk disease was defined as having any two of the following: i) three or more bone metastases seen on a bone scan, ii) Gleason sum $\geq 8$, and iii) any visceral metastases (12).

Frontline treatment included i) first line docetaxel, ii) AA, iii) ENZ and iv) cabazitaxel, while the treatment courses, the cumulative dosage, and the PSA decline percentage were listed for comparison. Docetaxel rechallenge was the same as the treatment schedule described in the first-line treatment. Parameters included i) PSA, ii) PSA doubling time (months), iii) alkaline phosphate (Alk-P), iv) lactate dehydrogenase (LDH), v) hemoglobin ( $\mathrm{Hb})$, and vi) albumin prior to rechallenge of docetaxel, with subsequent treatment after rechallenge of docetaxel collected, possibly related to the oncological outcome.

Statistics. End point evaluation using the Kaplain-Meier survival curve and the log-rank test were used to compare the overall survival (OS) from $\mathrm{mCRPC}$ and PSA progression-free survival (PFS) at different sequences of docetaxel. The continuous values were analyzed by the Mann-Whitney $U$-test and Fisher's exact test $t$-test for continuous variables. A $c h i^{2}$ test was used for categorical variables. Univariate and multivariate Cox hazard regression was used to estimate the hazard ratio (HR) and $95 \%$ confidence interval (CI) was used for the association between the variables and OS. Subgroups for overall survival hazard ratio analysis were used when discussing the advantage of docetaxel rechallenge in the different subgroups of patients. Analyses were performed using the SAS software, version 9.2 (SAS Institute, Inc., Cary, NC, USA). A pValue of $<0.05$ was considered statistically significant.

\section{Results}

Patient characteristics are described in Table I. The median follow-up time from mCRPC was 39.71 months in the rechallenge docetaxel group and 17.38 months in the nonrechallenge docetaxel group $(p<0.001)$. The age at diagnosis of mCRPC was younger in the rechallenge docetaxel group than the non-rechallenge docetaxel group (63.74 vs. 74.68 years, $p<0.001)$. Additionally, there was no difference in the initial PSA (98.82 vs. 131.00, $p=0.302)$, the nadir PSA at mHSPC ( $0.30 v s .0 .69, p=0.220)$, the hormone-sensitive state duration (32.07 vs. 28.97, $p=0.379)$, the Gleason score ( 8.50 vs. $9, p=0.843)$, nor in any underlying disease or metastatic sites between the two groups.

For frontline treatment with $1^{\text {st }}$ line docetaxel for mCRPC, as shown in Table I, patients received a median of 8 (range $=3-21$ ) cycles of docetaxel in the rechallenge docetaxel group and 5 (range $=1-44)$ cycles of docetaxel in the non-rechallenge docetaxel group $(p=0.001)$, while the cumulative dosage was 920 (range $=405-2,800) \mathrm{mg}$ and 535 (range $=75-5,160) \mathrm{mg}$ in each group, respectively $(p<0.001)$. 
Table I. Responses and adverse events of clinical trials with sequential CD19-directed chimeric antigen receptor T-cell and immune checkpoint inhibitor therapy.

\begin{tabular}{|c|c|c|c|c|c|}
\hline \multirow[b]{2}{*}{ Age } & \multicolumn{2}{|c|}{$\begin{array}{l}\text { Rechallenge } \\
\quad(n=24)\end{array}$} & \multicolumn{2}{|c|}{$\begin{array}{l}\text { Non-rechallenge } \\
\quad(\mathrm{n}=180)\end{array}$} & \multirow{2}{*}{$\frac{p \text {-Value }}{<0.001^{* *}}$} \\
\hline & 63.74 & $(48.09-81.57)$ & 74.68 & $(48.73-90.97)$ & \\
\hline Performance (ECOG, $\mathrm{n}=24$ vs. 179) & & & $0.018 *$ & & \\
\hline 0 & 16 & $(66.67 \%)$ & 70 & $(39.11 \%)$ & \\
\hline 1 & 8 & $(33.33 \%)$ & 83 & $(46.37 \%)$ & \\
\hline 2 & 0 & $(0.00 \%)$ & 26 & $(14.53 \%)$ & \\
\hline PSA at initial $(\mathrm{n}=23$ vs. 169) & 98.82 & $(5.91-3,100)$ & 131.00 & $(2.62-4,526)$ & 0.302 \\
\hline Nadire PSA at mHSPC $(\mathrm{n}=24$ vs. 175) & 0.30 & $(0-108)$ & 0.69 & $(0-812)$ & 0.220 \\
\hline Hormone sensitive duration & 32.07 & $(5.18-62.61)$ & 28.97 & $(3.11-352.29)$ & 0.379 \\
\hline $\mathrm{G} / \mathrm{S}(\mathrm{n}=20 v s .146)$ & 8.50 & $(7-10)$ & 9.00 & $(4-10)$ & 0.843 \\
\hline Hypertension & 9 & $(37.50 \%)$ & 64 & $(35.56 \%)$ & 1.000 \\
\hline Diabetes mellitusf & 0 & $(0.00 \%)$ & 22 & $(12.22 \%)$ & 0.083 \\
\hline Coronary artery diseasef & 3 & $(12.50 \%)$ & 21 & $(11.67 \%)$ & 1.000 \\
\hline BMI $(\mathrm{n}=24$ vs. 179) & 24.39 & $(19.69-33.59)$ & 24.28 & $(17.62-39.33)$ & 0.367 \\
\hline Bone metastasesf & 23 & $(95.83 \%)$ & 177 & $(98.33 \%)$ & 0.396 \\
\hline Lymph node metastasesf & 12 & $(50.00 \%)$ & 103 & $(57.22 \%)$ & 0.652 \\
\hline Lung metastases ${ }^{f}$ & 2 & $(8.33 \%)$ & 27 & $(15.00 \%)$ & 0.540 \\
\hline Liver metastases ${ }^{f}$ & 2 & $(8.33 \%)$ & 14 & $(7.78 \%)$ & 1.000 \\
\hline Brain metastases ${ }^{\mathrm{f}}$ & 1 & $(4.17 \%)$ & 6 & $(3.33 \%)$ & 0.589 \\
\hline \multicolumn{6}{|l|}{$1^{\text {st }}$ line Docetaxel } \\
\hline Cycle & 8.00 & $(3-21)$ & 5.00 & $(1-44)$ & $0.001 * *$ \\
\hline Cumulative dosage & 920.00 & $(405-2,800)$ & 535.00 & $(75-5,160)$ & $<0.001 * *$ \\
\hline PSA before Docetaxel & 28.91 & $(4.41-1,563)$ & 49.21 & $(1.1-5,989)$ & 0.294 \\
\hline PSA after Docetaxel ( $\mathrm{n}=24$ vs. 171) & 4.31 & $(0.08-1,837)$ & 17.40 & $(0-10,625)$ & $0.016^{*}$ \\
\hline PSA decline (percentage, $\%$ ) & -84.52 & $(-99.59-147.37)$ & -46.48 & $(-100-549.58)$ & $0.049 *$ \\
\hline Abiraterone treatment month $(\mathrm{n}=20$ vs. 62$)$ & 6.00 & $(2-42)$ & 9.00 & $(2-65)$ & 0.297 \\
\hline Abiraterone response ( $\mathrm{n}=20$ vs. 61 ) & 11.75 & $(-99.86-973.4)$ & -41.95 & $(-100-236.95)$ & 0.216 \\
\hline Enzalutamide treatment month $(\mathrm{n}=11$ vs. 18$)$ & 6.00 & $(2-12)$ & 5.50 & $(1-38)$ & 0.903 \\
\hline Enzalutamide response $(\mathrm{n}=11$ vs. 18$)$ & -15.22 & $(-89.2-118.34)$ & -63.01 & $(-99.99-33.84)$ & 0.084 \\
\hline Cabazitaxel cycle $(\mathrm{n}=7$ vs. 25$)$ & 4.00 & $(3-17)$ & 4.00 & $(1-16)$ & 0.771 \\
\hline Cabazitaxel response $(\mathrm{n}=7$ vs. 25$)$ & -25.48 & $(-94.68-75.23)$ & -52.00 & $(-99.99-142.49)$ & 0.346 \\
\hline Follow up time (months, from mCRPC) & 39.71 & $(14.86-114.32)$ & 17.38 & $(0.25-111.93)$ & $<0.001 * *$ \\
\hline
\end{tabular}

Mann-Whitney test. Chi-Square test. fFisher's Exact test. ${ }^{*} p<0.05$, ${ }^{*} p<0.01$. Continuous data were expressed as median (Range). Categorical data were expressed in numbers and percentages. mCRPC: Metastatic castration resistant prostate cancer; G/S: Gleason Score; PSA: prostatic specific antigen; mHSPC, metastatic hormone sensitive prostate cancer; BMI: body mass index.

After treatment with $1^{\text {st }}$ line docetaxel, PSA decline was $84.52 \%$ (range=-99.59-147.37) in the rechallenge docetaxel group and $-46.48 \%$ (range $=-100-549.58$ ) in the nonrechallenge docetaxel group $(p=0.049)$. Twenty patients in the rechallenge and 62 patients in the non-rechallenge group received AA with a median duration of 6 and 9 months, and a PSA response of $11.75 \%$ (range=-99.86-973.4) and $41.95 \%$ (range $=-100--236.95)$, both respectively. Eleven patients and 18 patients received ENZ in each group with a median of 6 months and 5.5 months duration, and a PSA response of $-15.22 \%$ (range $=-89.2-118.34$ ) and $-63.01 \%$ (range=-99.99--33.84), both respectively. Cabazitaxel was also used in each group $(n=7$ in the rechallenge $v s . n=25$ in the non-rechallenge group) and the PSA response was $25.48 \%$ (range $=-94.68-75.23)$ and $-52.00 \%$ (range $=-99.99$ $142.49)$, respectively $(p=0.346)$.
Regarding the 24 patients who received rechallenge docetaxel (Table II), 12 of them received it at the $3^{\text {rd }}$ line, 10 at the $4^{\text {th }}$ line and 2 at the $5^{\text {th }}$ line at mCRPC. The average number of rechallenge docetaxel cycles was 4 (range=1-17) and the cumulative dosage was 520 (range=100-2,260) $\mathrm{mg}$. The PSA doubling time was 1.85 months (range=0.7-7.7) prior to treatment. Values of alkaline phosphatase (Alk-P), lactate dehydrogenase (LDH), hemoglobin ( $\mathrm{Hb})$, Albumin and PSA are outlined in Table II. Fourteen of these 24 patients (58.33\%) achieved a PSA response (any decline of PSA after rechallenge docetaxel), while 9 of 24 patients $(37.5 \%)$ achieved a PSA decline $\geq 20 \%$ and $3(12.5 \%)$ achieved a PSA decline $\geq 50 \%$. The median follow-up time from rechallenge docetaxel was 12.05 months (range=2.86-52.34).

Most importantly, rechallenge docetaxel significantly improved the OS from mCRPC when compared to non- 
Table II. Patients characteristics at docetaxel rechallenge $(n=24)$.

\begin{tabular}{|c|c|c|}
\hline & $\begin{array}{l}\text { Median/ } \\
\text { number }\end{array}$ & $\begin{array}{l}\text { Range/ } \\
\text { percentage }\end{array}$ \\
\hline \multicolumn{3}{|l|}{ Docetaxel rechallenge sequence } \\
\hline $3^{\text {rd }}$ line & 12 & $50 \%$ \\
\hline $4^{\text {th }}$ line & 10 & $41.67 \%$ \\
\hline $5^{\text {th }}$ line & 2 & $8.33 \%$ \\
\hline $\begin{array}{l}\text { Treatment time from mCRPC } \\
\text { (months) }\end{array}$ & 29.68 & $(18.71-48.82)$ \\
\hline $\begin{array}{l}\text { Interval between prior and } \\
\text { rechallenge docetaxel (months) }\end{array}$ & 17.18 & $(7.93-31.93)$ \\
\hline Docetaxel cycles & 4.00 & $(1-17)$ \\
\hline Docetaxel cumulative dosage & 520.00 & $(100-2,260)$ \\
\hline PSA doubling time before & 1.85 & $(0.7-7.7)$ \\
\hline Alk-P $(n=20)$ & 178.50 & $(67-316)$ \\
\hline LDH $(n=18)$ & 237.00 & $(154-708)$ \\
\hline $\mathrm{Hb}$ & 10.65 & $(7-14.9)$ \\
\hline Albumin $(n=18)$ & 3.80 & $(2.7-4.5)$ \\
\hline PSA before docetaxel rechallenge & 299.50 & $(3.89-2,907)$ \\
\hline PSA after docetaxel rechallenge & 204.35 & $(3.84-2,417)$ \\
\hline PSA decline (percentage, $\%$ ) & -6.53 & $(-95.72-70.02)$ \\
\hline PSA response $\geq 0 \%$ & 14 & $58.33 \%$ \\
\hline PSA response $\geq 20 \%$ & 9 & $37.5 \%$ \\
\hline PSA response $\geq 30 \%$ & 4 & $16.67 \%$ \\
\hline PSA response $\geq 50 \%$ & 3 & $12.5 \%$ \\
\hline \multicolumn{3}{|l|}{ Subsequent Abiraterone courses $(n=0)$} \\
\hline Subsequent Enzalutamide courses $(n=4)$ & 5.00 & $(3-46)$ \\
\hline Subsequent Cabazitaxel cycles $(n=3)$ & 3.00 & $(2-11)$ \\
\hline $\begin{array}{l}\text { Follow up time from rechallenge } \\
\text { Docetaxel (months) }\end{array}$ & 12.05 & $(2.86-52.43)$ \\
\hline
\end{tabular}

Categorical data were expressed in numbers and percentages. Continuous data were expressed as median (Range). mCRPC: Metastatic castration resistant prostate cancer; PSA: prostatic specific antigen; Alk-P: alkaline phosphate; LDH: lactate dehydrogenase; Hb: hemoglobin.

rechallenge docetaxel (50.11 vs. 26.36 months, respectively, $p$ for log rank test $=0.044^{*}$ ) (Figure 1). While discussing the treatment efficacy of docetaxel in different sequences, this appears to have a median of 5.75 months (range=4.73-6.77) PFS in the first line at mCRPC and a median of 2.79 months (2.06-3.51) in the rechallenge sequence. Figure 2 demonstrates the OS from rechallenge docetaxel with a 13.82-month (range=10.94-16.70) survival time.

Uni- and multi-variant analyses for OS from mCRPC are shown in Table III. After adjustments, we found that i) the performance status score $2(\mathrm{HR}=2.46,95 \% \mathrm{CI}=1.32-4.58$, $\left.p=0.005^{* *}\right)$, ii) the hormone sensitive duration (HR=0.99, 95\% CI $=0.99-0.999, p=0.014 *$ ), iii) liver metastases (HR=1.90, $\left.95 \% \mathrm{CI}=1.04-3.47, p=0.036^{* *}\right)$, iv) brain metastases ( $\mathrm{HR}=2.23$, $95 \% \mathrm{CI}=1.26-5.46, p=0.015 * *)$ and $\mathrm{v})$ rechallenge with docetaxel $(\mathrm{HR}=0.59,95 \% \mathrm{CI}=0.32-0.99, p=0.046 * *)$ were the most significant factors affecting a patient's survivability.

Figure 3 shows the subgroup comparative analysis of the overall survival hazard ratio between the rechallenge docetaxel

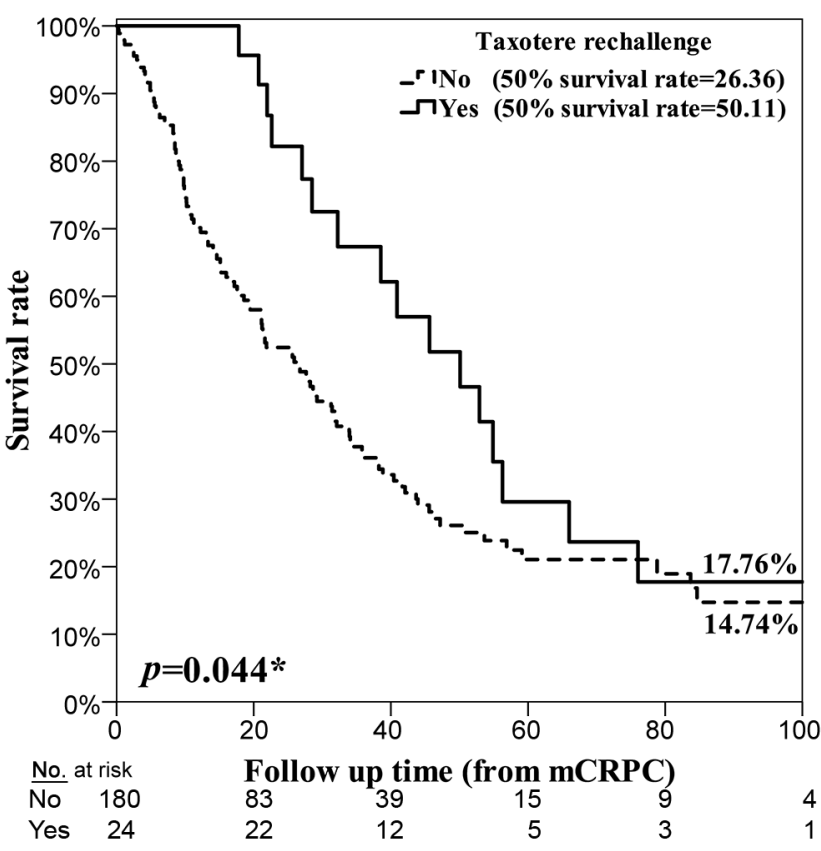

Figure 1. Kaplan-Meier curve for overall survival (OS) from metastatic castration resistant prostate cancer $(m C R P C)$ treated with and without docetaxel (taxotere) rechallenge ( $n=24 \mathrm{vs.} 180$, respectively), median 50.11 vs. 26.36 months ( $p$ for log rank test=0.044*).

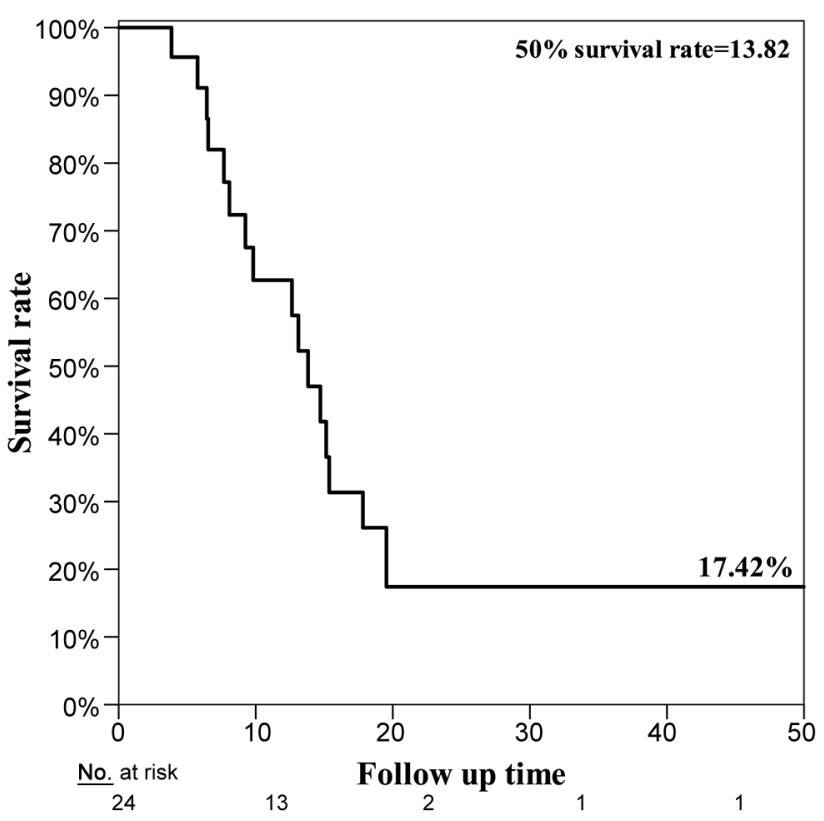

Figure 2. Kaplan-Meier curve for overall survival (OS). In metastatic castration resistant prostate cancer $(m C R P C)$ patients from rechallenge docetaxel $(n=24)$ OS was 13.82 months (range=10.94-16.70). 
Table III. Uni- and Multi-variant analysis for Overall Survival (OS) from mCRPC.

\begin{tabular}{|c|c|c|c|c|c|c|}
\hline & \multicolumn{3}{|c|}{ Univariate } & \multicolumn{3}{|c|}{ Multivariate } \\
\hline & HR & $95 \% \mathrm{CI}$ & $p$-Value & $\mathrm{HR}$ & $95 \% \mathrm{CI}$ & $p$-Value \\
\hline Age & 1.02 & $(1.0002-1.04)$ & $0.048^{*}$ & 1.00 & $(0.98-1.03)$ & 0.830 \\
\hline \multicolumn{7}{|l|}{ Performance } \\
\hline 0 & ref. & & & ref. & & \\
\hline 1 & 1.38 & $(0.95-2.00)$ & 0.091 & 1.29 & $(0.86-1.93)$ & 0.226 \\
\hline 2 & 2.94 & $(1.73-5.00)$ & $<0.001 * *$ & 2.46 & $(1.32-4.58)$ & $0.005 * *$ \\
\hline PSA at initial & 1.00 & $(1.00-1.00)$ & 0.405 & & & \\
\hline Nadir PSA at mHSPC & 1.00 & $(1.00-1.00)$ & 0.113 & & & \\
\hline Hormone sensitive duration & 0.995 & $(0.99-0.9996)$ & $0.031 *$ & 0.99 & $(0.99-0.999)$ & $0.014 *$ \\
\hline Gleason score & 0.99 & $(0.85-1.15)$ & 0.896 & & & \\
\hline BMI & 0.94 & $(0.90-0.99)$ & $0.022 *$ & 0.95 & $(0.91-1.00)$ & 0.061 \\
\hline Bone metastases & 1.81 & $(0.45-7.34)$ & 0.404 & & & \\
\hline Lymph node metastases & 1.27 & $(0.90-1.80)$ & 0.171 & & & \\
\hline Lung metastases & 1.63 & $(1.00-2.67)$ & 0.051 & & & \\
\hline Liver metastases & 2.13 & $(1.19-3.83)$ & $0.011 *$ & 1.90 & $(1.04-3.47)$ & $0.036^{*}$ \\
\hline Brain metastases & 3.07 & $(1.34-7.06)$ & $0.008 * *$ & 2.23 & $(1.26-5.46)$ & $0.015^{*}$ \\
\hline \multicolumn{7}{|l|}{ Docetaxel rechallenge } \\
\hline Non rechallenge & ref. & ref. & & & & \\
\hline Rechallenge & 0.59 & $(0.35-0.99)$ & $0.047 *$ & 0.59 & $(0.32-0.99)$ & $0.046^{*}$ \\
\hline
\end{tabular}

Cox regression. ${ }^{*} p<0.05$, ${ }^{*} p<0.01$. mCRPC: Metastatic castration resistant prostate cancer; PSA: prostatic specific antigen; mHSPC: metastatic hormone sensitive prostate cancer; BMI body mass index.

(left side) and non-rechallenge docetaxel (right side) group. Rechallenge docetaxel was beneficial for the overall survival in the following subgroups: i) ages ( $\geq 75$ years old or $<75$ years old), ii) performance status (0 or 1$)$, iii) initial PSA $(\geq 100$ or $<100)$, iv) Gleason score $(\geq 8$ or $<8)$, v) bone metastases only, vi) visceral metastases, vii) metastases volume (high volume or low volume), viii) metastatic risk (high or low risk), ix) hormone-sensitive state duration $(\geq 12$ months or $<12$ months), $\mathrm{x}$ ) nadir PSA at $\operatorname{mHSPC}(<1$ or $>1)$, and xi) $1^{\text {st }}$ line docetaxel response (response or non-response). Additionally, rechallenge docetaxel improved overall survival in the high metastases volume $(\mathrm{HR}=0.34,95 \% \mathrm{CI}=0.15-0.75$, $\left.p=0.008^{* *}\right)$, high metastases risk $(\mathrm{HR}=0.41,95 \% \mathrm{CI}=0.17$ $\left.0.96, p=0.040^{* *}\right)$ and ARAT non response (HR=0.36, $95 \% \mathrm{CI}=0.17-0.78, p=0.010 * *)$ subgroups.

The adverse events are shown in Table IV. Seven patients $(29.17 \%)$ suffered from Grade 3/4 neutropenia, while 5 patients $(20.83 \%)$ suffered from Grade $1 / 2$ neutropenia, both of which were tolerable and manageable. Thrombocytopenia $(16.67 \%)$, anemia $(25.00 \%)$, skin rash $(4.17 \%)$, fatigue $(45.83 \%)$, elevation of aspartate transaminase/alanine transaminase (AST/ALT) $(4.17 \%)$, nausea $(25.00 \%)$, diarrhea $(12.5 \%)$ and nail disorder $(4.17 \%)$ were also observed.

\section{Discussion}

Docetaxel for patients with mCRPC was first established in 2004 and has been widely used in them for more than ten years. Ever since the announcement of AA and ENZ in 2012, most patients have received AA or ENZ as a prior treatment, due to its favorable durability and tolerability $(3,5)$. Treatment options offered after failure of prior ARAT include cabazitaxel, radium-223 or another type of ARAT. Rechallenge docetaxel was meant to be an alternative to other expensive drugs, but there is not enough evidence of its usefulness. The current study is the first to have identified the efficacy of rechallenge docetaxel for mCRPC after failure of first line docetaxel and androgen receptor-axistargeted therapies, particularly for those patients who are non-responsive to ARATs.

Docetaxel is a semisynthetic texane which binds to $\beta$ tubulin incorporated with microtubules during the $\mathrm{G}_{2}-\mathrm{M}$ phase to trigger cell death in proliferating tumor cells (13). Several mechanisms surrounding the resistance to docetaxel include: i) the overexpression of membrane-bound efflux proteins, which decrease cellular drug accumulation; ii) altered expression of tubulin isotypes or microtubuleassociated proteins (for example, overexpression of $\beta$ IIItubulin), and iii) changes to the microtubules that are induced by interactions with other cytoskeletal proteins (for example, $\gamma$-actin), causing defects in apoptotic pathways (14). Previous studies have attempted to overcome the resistance of prostate cancer to docetaxel through the simultaneous use of bevacizumab, epirubicin and carboplatin, but have been limited by their small size cohorts and inconsistent results (15-17). Furthermore, the available 


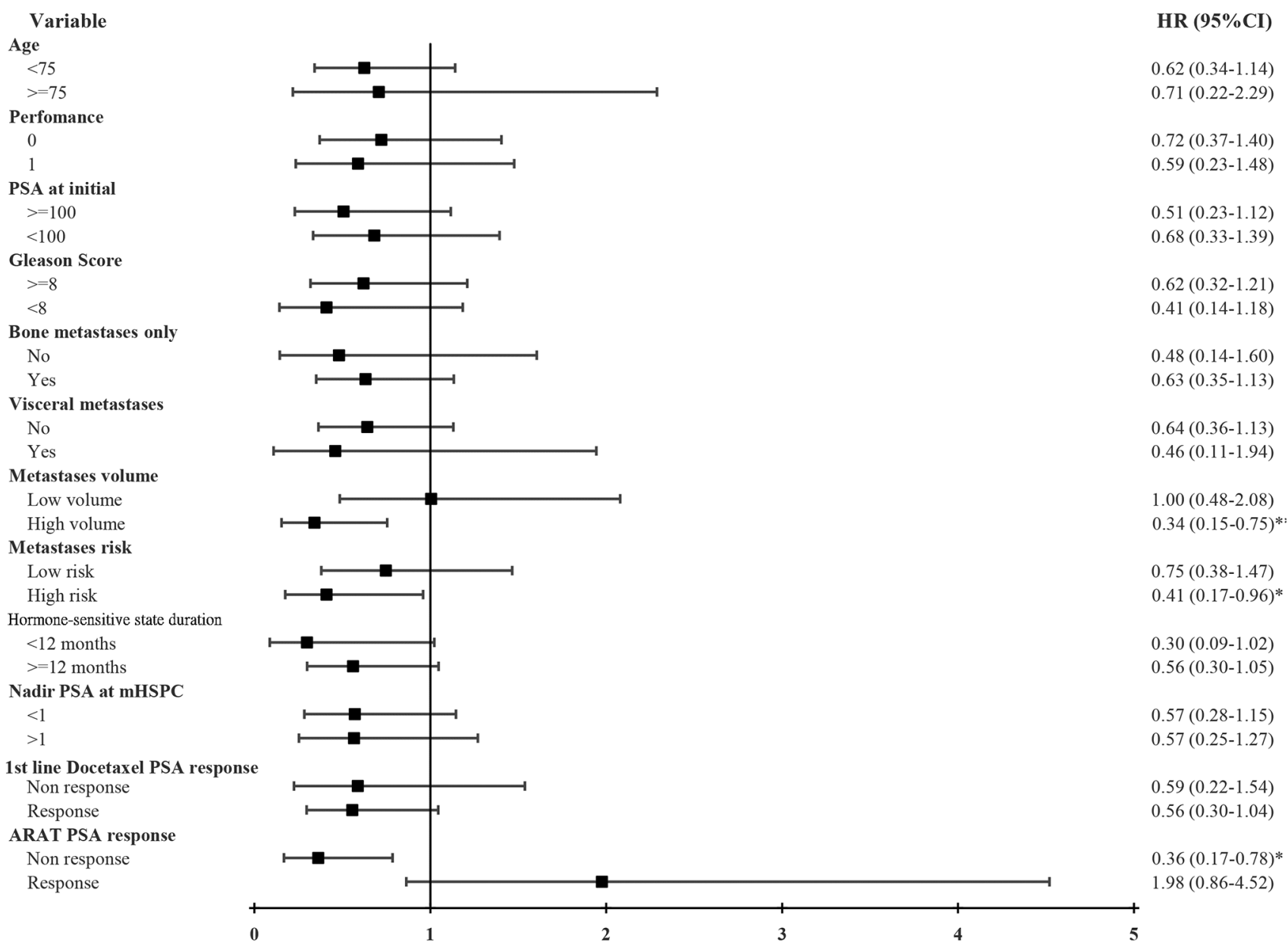

Figure 3. Subgroup analysis for overall survival hazard ratio in metastatic castration resistant prostate cancer ( $m$ CRPC) patients received docetaxel rechallenge (left side) and without docetaxel rechallenge (right side). HR: Hazard ratio; CI: confidence interval; PSA: prostatic specific antigen; mHSPC: metastatic hormone sensitive prostate cancer.

literature has revealed that docetaxel retreatment seems to be an option in patient response to prior line docetaxel during a minimum progression-free interval of 3-6 months, but is limited in intermittent treatment strategy in mCRPC (18).

In in vitro experiments, exposure of prostate cancer cells to taxane-based chemotherapy can inhibit the androgen receptor (AR) nuclear translocation by targeting the AR association with tubulin, leading to a nucleus that is significantly depleted of AR (19). The same result has also been observed in circulating tumor cells isolated from the peripheral blood of mCRPC patients, which correlates to the clinical response to taxane-based chemotherapy (20). Prior hormonal treatment may influence the docetaxel response. Marín-Aguilera et al., have reported that Enzalutamide can induce the expression of neuroendocrine markers, such as Chromogranin $\mathrm{A}$ and synaptophysin, and reduce E-cadherin, leading to reduced docetaxel-induced cytotoxicity in $\mathrm{VCaP}$ prostate cancer cells (21). Similarly, van Soest et al., have also found an impaired efficacy of docetaxel, cabazitaxel and enzalutamide in the abiraterone-resistant cell line, suggesting cells' cross-resistance in the presence of certain hormones (22).

Regarding mCRPC patient failure to prior docetaxel and ARAT treatments, several drugs offer efficacies and survival benefits. The CARD trial, a phase III randomized control study, introduced cabazitaxel as being the most effective treatment after docetaxel and progression on one line of ARTA within 12 months (23). Alpha emitter radium-223 has been another option for mCRPC patients with bone metastases, solely based upon patients' improvement in overall survival and pain relief (24). Abiraterone acetate after enzalutamide failure or vice versa could be a reasonable choice, but there is cross resistance between one another, and the potency is limited. Reports have stated that while there is a $36 \%$ enzalutamide response rate after abiraterone acetate failure, there is only a $4 \%$ abiraterone acetate response rate after enzalutamide failure (25-27). Other treatment options 
Table IV. Adverse events for docetaxel rechallenge $(n=24)$.

\begin{tabular}{lccccc}
\hline & \multicolumn{2}{c}{ Grade $1 / 2$} & & \multicolumn{2}{c}{ Grade 3/4 } \\
\cline { 2 - 3 } \cline { 5 - 6 } & $\mathrm{n}$ & $\%$ & & $\mathrm{n}$ & $\%$ \\
\hline Neutropenia & 5 & $(20.83 \%)$ & & 7 & $(29.17 \%)$ \\
Thrombocytopneia & 4 & $(16.67 \%)$ & & $(0 \%)$ \\
Anemia & 6 & $(25.00 \%)$ & & 0 & $(0 \%)$ \\
Rash & 1 & $(4.17 \%)$ & & 0 & $(0 \%)$ \\
Fatigue & 11 & $(45.83 \%)$ & & 0 & $(0 \%)$ \\
Elevated AST/ALT & 1 & $(4.17 \%)$ & & $(0 \%)$ \\
Nausea/vomiting & 6 & $(25.00 \%)$ & & 0 & $(0 \%)$ \\
Diarrhea & 3 & $(12.5 \%)$ & & 0 & $(0 \%)$ \\
Nail disorder & 1 & $(4.17 \%)$ & & 0 & $(0 \%)$ \\
\hline
\end{tabular}

Categorical data are expressed in numbers and percentages. AST/ALT: Aspartate transaminase/alanine transaminase.

include the poly (adenosine diphosphate (ADP)-ribose) polymerase (PARP) inhibition using olaparib in mCRPC patients with DNA-repair gene defects (28). Nevertheless, the concern regarding the above medication is that it is expensive and has limited access. Rechallenge docetaxel in later lines could be an alternative for all these patients with advanced disease and as our previous study found, rechallenge docetaxel had a $62.5 \%$ response rate compared to AA non-responsive patients (29).

One possible reason explaining the efficacy of docetaxel rechallenge after failure of ARAT may be associated with the expression of the androgen-receptor splice variant 7 (AR-V7) in the neoplastic clones, causing resistance to novel androgen target agents (30). In contrast, expression of AR-V7 in circulating tumor cells does not appear to be associated with primary resistance to taxane-based chemotherapy (31). The presence of AR in plasma may be another explanation for the diversity of mCRPC responses to docetaxel and ARAT. Conteduca et al. have reported in a multi-institutional study with pooled analysis, that the normal AR status responds well to hormonal therapy whilst plasma AR-gained may have a longer response to docetaxel (32).

Several studies have also addressed the efficacy of rechallenge docetaxel in the progression of mCRPC. The retrospective extended follow up from the GETUG-AFU 15 phase III clinical trial has identified a PSA decline of $\geq 50 \%$ at first line rechallenge docetaxel in 4 out of 20 patients $(20 \%)$, with a median 4.1-month progression-free survival period for those who had received upfront docetaxel in mHSPC (33). Di Lorenzo et al. have also reported a $24.5 \%$ partial PSA response in 45 patients initially responding to docetaxel in mCRPC, and then experiencing progression after a period of biochemical remission of at least 5 months (7). Additionally, Eymard et al., have reported 148 mCRPC patients who responded well to first line docetaxel, received docetaxel rechallenge in second (52\% of patients) and third line (48\% of patients), with a $48 \%$ of patients achieving a PSA decline of $\geq 50 \%$ and a median overall survival of 16 months from docetaxel rechallenge. The grade 3-4 adverse events were limited to nail disorders (12\%), edema/weight gain $(8 \%)$, and hematological side effects (6\%) (8).

Furthermore, Loriot et al. have reported a cohort of 39 mCRPC patients who received docetaxel rechallenge and showed a $38 \%$ PSA decline occurring in more than $50 \%$ of cases, in addition to a median of 4.3 months progression-free survival and a15.8-month overall survival. The treatment interval from the last cycle of docetaxel to rechallenge docetaxel less than three months was associated with a shorter progression-free survival (34). Thomas et al., have also reported 62 patients that received rechallenge docetaxel and had a PSA-response at first docetaxel-sequence at $48.4 \%$ $(\mathrm{n}=62)$, at rechallenge $31.6 \%(\mathrm{n}=32)$, and at third-sequence $34.8 \%(n=22)$ docetaxel, respectively while most benefit in treatment-free interval more than three months (9). Heck et $a l$. , have further reported 44 patients retreated with docetaxel that had a reduction in PSA levels of $\geq 50 \%$ after first-line docetaxel, correlating with superior PSA progression free survival and overall survival (35). Di Lorenzo et al., have also reported a case of heavily pretreated mCRPC that benefited clinically from 4 cycles of docetaxel and suffered minimal toxicity (36).

There are also conflicting results about the survival benefits of mCRPC patients treated with doctaxel rechallenge. Oudard et al., have reported the largest cohort of 270 mCRPC patients from 2009 to 2011 and a good response (PSA decrease of $\geq 50 \%$ ) to first line docetaxel. There was $40.4 \%$ good PSA response and a symptom relief/stable disease in the rechallenge docetaxel group $(n=223)$; however, there was no survival benefit compared to second line non-taxane-based therapy $(n=47)$ (37). The difference between this study and ours may be due to the fact that the former study examined a second line treatment setting whilst our data addressed the effect of docetaxel rechallenge in mCRPC patients from different treatment sequences, including patient having received abiraterone acetate and enzalutamide treatments.

One interesting study has addressed the possibility of cross resistance between abiraterone and docetaxel. Schweizer et al., have reported on 24 patients who received docetaxel after prior abiraterone acetate and were compared to 95 patients who received docetaxel only. Prior abiraterone acetate was associated with a shorter progression free survival (4.4 vs. 7.6 months, respectively) and a less frequent PSA decline $\geq 50 \%$ compared to docetaxel only ( $38 \% v s$. $63 \%$, respectively) (38).

Our study is the first one reporting on the survival benefits of rechallenge docetaxel in relation to abiraterone acetate and enzalutamide. The response rate of PSA decline of $\geq 30 \%$ 
was found in only $16.67 \%$ of our cohort, which is less than in former studies; however, this may be due to the late sequence of rechallenge docetaxel. All our participants were exposed to at least one line of ARAT leading to a longer rechallenge interval (median of 17.18 months from the last time of first line docetaxel). Nevertheless, $58.33 \%$ of our patients benefited from rechallenge docetaxel by PSA decline at such an advanced disease stage. Our data also suggest that rechallenge docetaxel can improve overall survival when compared to the survival of patients without rechallenge, while adverse events were both few and manageable. In two clinical trial settings, there was only a $29 \%$ PSA response to abiraterone after docetaxel (COU-AA 301), and a 54\% response to enzalutamide after docetaxel (AFFIRM) $(3,5)$. Excluding patients who respond to ARATs, rechallenge docetaxel could be a good alternative according to our findings, since rechallenge docetaxel provided a significant improvement in patients' overall survival.

Adverse events were the most concerning points for docetaxel rechallenge. The incidence of neutropenia was high in our study population but it could be managed with granulocyte colony-stimulating factor. In the largest reported data about docetaxel rechallenge, neutropenic complications usually occur at cycle 1 and the incidence decreases by treatment sequencing (37). Another study in 46 patients treated with docetaxel rechallenge reported only a limited number of major adverse events, while no patient had to stop a rechallenge because of toxicity and there were no treatmentrelated deaths (39). This study also concluded that docetaxel rechallenge may be safely repeated several times in mCRPC patients and suggested that in selected patients it could improve disease control. Nevertheless, cumulative toxicity associated with docetaxel should be a caution in grade 3 to 4 patients, as nail disorders increase from $4.6 \%$ to $7.9 \%$ in those receiving $1^{\text {st }}$ and $2^{\text {nd }}$ docetaxel rechallenge (39).

There were some limitations in our study. Inevitably, retrospective settings made a selection bias with regards to a younger age and the performance status, which offer a better response in the docetaxel rechallenge group. Our case number was small and the intergroup difference also limited the application of our results. Although the goal of our study was to try to identify the efficacy of docetaxel rechallenge in patients with $\mathrm{mCRPC}$, the non-rechallenge group included patients with primary resistance, whereas patients in the rechallenge group received at least three lines of CRPC therapy. This makes the two groups imbalanced and the comparison between them possibly unjust. Additionally, the higher proportion of bone metastases and less visceral metastases in our cohort possibly expand the survival time compared to the published clinical trial with only about $90 \%$ of bone metastases (1-6). Use of ARATs as a first line treatment for $\mathrm{mCRPC}$ in recent years and more upfront docetaxel in mHSPC, which was excluded from our study, would restrict the application of the knowledge emerging from our data.

Finally, our real-world analysis is the first one to show evidence for the usefulness of docetaxel rechallenge in relation to ARATs. As a result, $\mathrm{mCRPC}$ patients receiving several lines of treatment could possibly benefit from docetaxel if novel agents are unavailable or unaffordable.

In conclusion, the docetaxel rechallenge improved the survival of patients with mCRPC after the failure of first line docetaxel and subsequent abiraterone acetate or enzalutamide. Independent predictive factors for overall survival included: i) the performance status, ii) the hormonesensitive state duration, iii) liver and iv) brain metastases. Patients with a high metastases volume, high metastases risk and non-responsive to ARATs wound benefited from the use of rechallenge docetaxel with respect to overall survival.

\section{Conflicts of Interest}

The contributing Authors have no conflicts of interest, including specific financial interests or relationships and affiliations relevant to the subject matter or materials discussed in the manuscript.

\section{Authors' Contributions}

Conceived and designed the analysis: SCH, JRL, KevinL and KYC. Data collection and statistic analysis: SCH, LWC and SSW. Contribution of study patients: SSW, CKY, CSC, SCW, CYL, CLC, YCO, KYC. Paper drift: SCH and LWC. Supervisor: KYC

\section{Acknowledgements}

We wish to offer our thanks to the personnel at the Cancer Registry database from the Cancer Prevention and Control Center in Taichung Veterans General Hospital for their support with regards to providing the clinical data.

\section{References}

1 Petrylak DP, Tangen CM, Hussain MH, Lara PN Jr, Jones JA, Taplin ME, Burch PA, Berry D, Moinpour C, Kohli M, Benson MC, Small EJ, Raghavan D and Crawford ED: Docetaxel and estramustine compared with mitoxantrone and prednisone for advanced refractory prostate cancer. N Engl J Med 351(15): 15131520, 2004. PMID: 15470214. DOI:10.1056/NEJMoa041318

2 Tannock IF, de Wit R, Berry WR, Horti J, Pluzanska A, Chi KN, Oudard S, Théodore C, James ND, Turesson I, Rosenthal MA, Eisenberger MA and TAX 327 Investigators: Docetaxel plus prednisone or mitoxantrone plus prednisone for advanced prostate cancer. N Engl J Med 351(15): 1502-1512, 2004. PMID: 15470213. DOI: 10.1056/NEJMoa040720

3 de Bono JS, Logothetis CJ, Molina A, Fizazi K, North S, Chu L, Chi KN, Jones RJ, Goodman OB Jr, Saad F, Staffurth JN, Mainwaring P, Harland S, Flaig TW, Hutson TE, Cheng T, Patterson H, Hainsworth JD, Ryan CJ, Sternberg CN, Ellard SL, Fléchon A, Saleh M, Scholz M, Efstathiou E, Zivi A, Bianchini D, Loriot Y, Chieffo N, Kheoh T, Haqq CM, Scher HI and COU- 
AA-301 Investigators: Abiraterone and increased survival in metastatic prostate cancer. N Engl J Med 364(21): 1995-2005, 2011. PMID: 21612468. DOI: 10.1056/NEJMoa1014618

4 Ryan CJ, Smith MR, de Bono JS, Molina A, Logothetis CJ, de Souza P, Fizazi K, Mainwaring P, Piulats JM, Ng S, Carles J, Mulders PF, Basch E, Small EJ, Saad F, Schrijvers D, Van Poppel H, Mukherjee SD, Suttmann H, Gerritsen WR, Flaig TW, George DJ, Yu EY, Efstathiou E, Pantuck A, Winquist E, Higano CS, Taplin ME, Park Y, Kheoh T, Griffin T, Scher HI, Rathkopf DE and COU-AA-302 Investigators: Abiraterone in metastatic prostate cancer without previous chemotherapy. N Engl J Med 368(2): 138-148, 2013. PMID: 23228172. DOI: 10.1056/ NEJMoa1209096

5 Scher HI, Fizazi K, Saad F, Taplin ME, Sternberg CN, Miller K, de Wit R, Mulders P, Chi KN, Shore ND, Armstrong AJ, Flaig TW, Fléchon A, Mainwaring P, Fleming M, Hainsworth JD, Hirmand M, Selby B, Seely L, de Bono JS and AFFIRM Investigators: Increased survival with enzalutamide in prostate cancer after chemotherapy. N Engl J Med 367(13): 1187-1197, 2012. PMID: 22894553. DOI: 10.1056/NEJMoa1207506

6 Beer TM, Armstrong AJ, Rathkopf DE, Loriot Y, Sternberg CN, Higano CS, Iversen P, Bhattacharya S, Carles J, Chowdhury S, Davis ID, de Bono JS, Evans CP, Fizazi K, Joshua AM, Kim CS, Kimura G, Mainwaring P, Mansbach H, Miller K, Noonberg SB, Perabo F, Phung D, Saad F, Scher HI, Taplin ME, Venner PM, Tombal B and PREVAIL Investigators: Enzalutamide in metastatic prostate cancer before chemotherapy. N Engl J Med 371(5): 424-433, 2014. PMID: 24881730. DOI: 10.1056/ NEJMoa1405095

7 Di Lorenzo G, Buonerba C, Faiella A, Rescigno P, Rizzo M, Autorino R, Perdonà S, Riccardi N, Scagliorini S, Scognamiglio F, Masala D, Ferro M, Palmieri G, Aieta M, Marinelli A, Altieri V, De Placido S and Cartenì G: Phase II study of docetaxel retreatment in docetaxel-pretreated castration-resistant prostate cancer. BJU Int 107(2): 234-239, 2011. PMID: 20590545. DOI: 10.1111/j.1464-410X.2010.09498.x

8 Eymard JC, Oudard S, Gravis G, Ferrero JM, Theodore C, Joly F, Priou F, Krakowski I, Zannetti A, Thill L and Beuzeboc P: Docetaxel reintroduction in patients with metastatic castrationresistant docetaxel-sensitive prostate cancer: a retrospective multicentre study. BJU Int 106(7): 974-978, 2010. PMID: 20230389. DOI: 10.1111/j.1464-410X.2010.09296.x

9 Thomas C, Brandt MP, Baldauf S, Tsaur I, Frees S, Borgmann H, Jäger W, Bartsch G, Schneider M, Dotzauer R, Neisius A and Haferkamp A: Docetaxel-rechallenge in castration-resistant prostate cancer: defining clinical factors for successful treatment response and improvement in overall survival. Int Urol Nephrol 50(10): 1821-1827, 2018. PMID: 30120678. DOI: 10.1007/ s11255-018-1963-1

10 Scher HI, Halabi S, Tannock I, Morris M, Sternberg CN, Carducci MA, Eisenberger MA, Higano C, Bubley GJ, Dreicer R, Petrylak D, Kantoff P, Basch E, Kelly WK, Figg WD, Small EJ, Beer TM, Wilding G, Martin A, Hussain M and Prostate Cancer Clinical Trials Working Group: Design and end points of clinical trials for patients with progressive prostate cancer and castrate levels of testosterone: recommendations of the Prostate Cancer Clinical Trials Working Group. J Clin Oncol 26(7): 11481159, 2008. PMID: 18309951. DOI: 10.1200/JCO.2007.12.4487

11 Sweeney CJ, Chen YH, Carducci M, Liu G, Jarrard DF, Eisenberger M, Wong YN, Hahn N, Kohli M, Cooney MM,
Dreicer R, Vogelzang NJ, Picus J, Shevrin D, Hussain M, Garcia JA and DiPaola RS: Chemohormonal therapy in metastatic hormone-sensitive prostate cancer. N Engl J Med 373(8): 737746, 2015. PMID: 26244877. DOI: 10.1056/NEJMoa1503747

12 Fizazi K, Tran N, Fein L, Matsubara N, Rodriguez-Antolin A, Alekseev BY, Özgüroğlu M, Ye D, Feyerabend S, Protheroe A, De Porre P, Kheoh T, Park YC, Todd MB, Chi KN and LATITUDE Investigators: Abiraterone plus prednisone in metastatic, castration-sensitive prostate cancer. N Engl J Med 377(4): 352-360, 2017. PMID: 28578607. DOI: 10.1056/ NEJMoa1704174

13 Kavallaris M: Microtubules and resistance to tubulin-binding agents. Nat Rev Cancer 10(3): 194-204, 2010. PMID: 20147901. DOI: $10.1038 / \mathrm{nrc} 2803$

14 Seruga B, Ocana A and Tannock IF: Drug resistance in metastatic castration-resistant prostate cancer. Nat Rev Clin Oncol 8(1): 12-23, 2011. PMID: 20859283. DOI: 10.1038/ nrclinonc.2010.136

15 Petrioli R, Roviello G, Fiaschi AI, Laera L, Miano ST, De Rubertis G, Barbanti G, Bianco V, Brozzetti S and Francini E: Rechallenge of docetaxel combined with epirubicin given on a weekly schedule in advanced castration-resistant prostate cancer patients previously exposed to docetaxel and abiraterone acetate: a single-institution experience. Med Oncol 32(3): 52, 2015. PMID: 25636506. DOI: 10.1007/s12032-015-0485-2

16 Di Lorenzo G, Figg WD, Fossa SD, Mirone V, Autorino R, Longo N, Imbimbo C, Perdonà S, Giordano A, Giuliano M, Labianca R and De Placido S: Combination of bevacizumab and docetaxel in docetaxel-pretreated hormone-refractory prostate cancer: a phase 2 study. Eur Urol 54(5): 1089-1094, 2008. PMID: 18276061. DOI: 10.1016/j.eururo.2008.01.082

17 Bouman-Wammes EW, van den Berg HP, de Munck L, Beeker A, Smorenburg CH, Vervenne WL, Coenen JLLM, Verheul HMW, Gerritsen WR and Van den Eertwegh AJM: A randomised phase II trial of docetaxel versus docetaxel plus carboplatin in patients with castration-resistant prostate cancer who have progressed after response to prior docetaxel chemotherapy: The RECARDO trial. Eur J Cancer 90: 1-9, 2018. PMID: 29268139. DOI: $10.1016 /$ j.ejca.2017.11.021

18 Assi T, Rassy E, Farhat F, Kattan C and Kattan J: Docetaxel rechallenge in patients with metastatic prostate cancer: a comprehensive review. Oncol Res Treat 43(6): 299-306, 2020. PMID: 32380503. DOI: 10.1159/000506693

19 Zhu ML, Horbinski CM, Garzotto M, Qian DZ, Beer TM and Kyprianou N: Tubulin-targeting chemotherapy impairs androgen receptor activity in prostate cancer. Cancer Res 70(20): 79928002, 2010. PMID: 20807808. DOI: 10.1158/0008-5472.CAN$10-0585$

20 Darshan MS, Loftus MS, Thadani-Mulero M, Levy BP, Escuin D, Zhou XK, Gjyrezi A, Chanel-Vos C, Shen R, Tagawa ST, Bander NH, Nanus DM and Giannakakou P: Taxane-induced blockade to nuclear accumulation of the androgen receptor predicts clinical responses in metastatic prostate cancer. Cancer Res 71(18): 6019-6029, 2011. PMID: 21799031. DOI: 10.1158/0008-5472.CAN-11-1417

21 Marín-Aguilera M, Reig Ò, Milà-Guasch M, Font A, Domènech M, Rodríguez-Vida A, Carles J, Suárez C, Del Alba AG, Jiménez N, Victoria I, Sala-González N, Ribal MJ, López S, Etxaniz O, Anguera G, Maroto P, Fernández PL, Prat A and Mellado B: The influence of treatment sequence in the prognostic value of 
TMPRSS2-ERG as biomarker of taxane resistance in castrationresistant prostate cancer. Int J Cancer 145(7): 1970-1981, 2019. PMID: 30807643. DOI: 10.1002/ijc.32238

22 van Soest RJ, van Royen ME, de Morrée ES, Moll JM, Teubel W, Wiemer EA, Mathijssen RH, de Wit R and van Weerden WM: Cross-resistance between taxanes and new hormonal agents abiraterone and enzalutamide may affect drug sequence choices in metastatic castration-resistant prostate cancer. Eur J Cancer 49(18): 3821-3830, 2013. PMID: 24200698. DOI: 10.1016/j.ejca.2013.09.026

23 de Wit R, de Bono J, Sternberg CN, Fizazi K, Tombal B, Wülfing C, Kramer G, Eymard JC, Bamias A, Carles J, Iacovelli R, Melichar B, Sverrisdóttir Á, Theodore C, Feyerabend S, Helissey C, Ozatilgan A, Geffriaud-Ricouard C, Castellano D and CARD Investigators: Cabazitaxel versus abiraterone or enzalutamide in metastatic prostate cancer. $\mathrm{N}$ Engl J Med 381(26): 2506-2518, 2019. PMID: 31566937. DOI: 10.1056/NEJMoa1911206

24 Parker C, Nilsson S, Heinrich D, Helle SI, O’Sullivan JM, Fosså SD, Chodacki A, Wiechno P, Logue J, Seke M, Widmark A, Johannessen DC, Hoskin P, Bottomley D, James ND, Solberg A, Syndikus I, Kliment J, Wedel S, Boehmer S, Dall'Oglio M, Franzén L, Coleman R, Vogelzang NJ, O’Bryan-Tear CG, Staudacher K, Garcia-Vargas J, Shan M, Bruland ØS, Sartor O and ALSYMPCA Investigators: Alpha emitter radium-223 and survival in metastatic prostate cancer. N Engl J Med 369(3): 213223, 2013. PMID: 23863050. DOI: 10.1056/NEJMoa1213755

25 Badrising S, van der Noort V, van Oort IM, van den Berg HP, Los M, Hamberg P, Coenen JL, van den Eertwegh AJ, de Jong IJ, Kerver ED, van Tinteren $\mathrm{H}$ and Bergman AM: Clinical activity and tolerability of enzalutamide (MDV3100) in patients with metastatic, castration-resistant prostate cancer who progress after docetaxel and abiraterone treatment. Cancer 120(7): 968975, 2014. PMID: 24382803. DOI: 10.1002/cncr.28518

26 Attard G, Borre M, Gurney H, Loriot Y, Andresen-Daniil C, Kalleda R, Pham T, Taplin ME and PLATO collaborators: Abiraterone alone or in combination with enzalutamide in metastatic castration-resistant prostate cancer with rising prostate-specific antigen during enzalutamide treatment. J Clin Oncol 36(25): 2639-2646, 2018. PMID: 30028657. DOI: 10.1200/JCO.2018.77.9827

27 Khalaf DJ, Annala M, Taavitsainen S, Finch DL, Oja C, Vergidis J, Zulfiqar M, Sunderland K, Azad AA, Kollmannsberger CK, Eigl BJ, Noonan K, Wadhwa D, Attwell A, Keith B, Ellard SL, Le L, Gleave ME, Wyatt AW and Chi KN: Optimal sequencing of enzalutamide and abiraterone acetate plus prednisone in metastatic castration-resistant prostate cancer: a multicentre, randomised, open-label, phase 2, crossover trial. Lancet Oncol 20(12): 1730-1739, 2019. PMID: 31727538. DOI: 10.1016/ S1470-2045(19)30688-6

28 Mateo J, Carreira S, Sandhu S, Miranda S, Mossop H, PerezLopez R, Nava Rodrigues D, Robinson D, Omlin A, Tunariu N, Boysen G, Porta N, Flohr P, Gillman A, Figueiredo I, Paulding C, Seed G, Jain S, Ralph C, Protheroe A, Hussain S, Jones R, Elliott T, McGovern U, Bianchini D, Goodall J, Zafeiriou Z, Williamson CT, Ferraldeschi R, Riisnaes R, Ebbs B, Fowler G, Roda D, Yuan W, Wu YM, Cao X, Brough R, Pemberton H, A'Hern R, Swain A, Kunju LP, Eeles R, Attard G, Lord CJ, Ashworth A, Rubin MA, Knudsen KE, Feng FY, Chinnaiyan $\mathrm{AM}$, Hall E and de Bono JS: DNA-repair defects and olaparib in metastatic prostate cancer. N Engl J Med 373(18): 1697-1708, 2015. PMID: 26510020. DOI: 10.1056/NEJMoa1506859

29 Hung SC, Wang SS, Li JR, Chen MC, Yang CK, Chen CS, Ho $\mathrm{HC}$, Chiu KY, Cheng CL, Chang CH and Ou YC: Outcome of patients with metastatic castration-resistant prostate cancer after PSA progression with abiraterone acetate. Anticancer Res 38(9): 5429-5436, 2018. PMID: 30194199. DOI: 10.21873/anticanres. 12874

30 Antonarakis ES, Lu C, Wang H, Luber B, Nakazawa M, Roeser JC, Chen Y, Mohammad TA, Chen Y, Fedor HL, Lotan TL, Zheng Q, De Marzo AM, Isaacs JT, Isaacs WB, Nadal R, Paller CJ, Denmeade SR, Carducci MA, Eisenberger MA and Luo J: $\mathrm{AR}-\mathrm{V} 7$ and resistance to enzalutamide and abiraterone in prostate cancer. N Engl J Med 371(11): 1028-1038, 2014. PMID: 25184630. DOI: 10.1056/NEJMoa1315815

31 Antonarakis ES, Lu C, Luber B, Wang H, Chen Y, Nakazawa M, Nadal R, Paller CJ, Denmeade SR, Carducci MA, Eisenberger MA and Luo J: Androgen receptor splice variant 7 and efficacy of taxane chemotherapy in patients with metastatic castrationresistant prostate cancer. JAMA Oncol 1(5): 582-591, 2015. PMID: 26181238. DOI: 10.1001/jamaoncol.2015.1341

32 Conteduca V, Jayaram A, Romero-Laorden N, Wetterskog D, Salvi S, Gurioli G, Scarpi E, Castro E, Marin-Aguilera M, Lolli C, Schepisi G, Maugeri A, Wingate A, Farolfi A, Casadio V, Medina A, Puente J, Vidal MJM, Morales-Barrera R, VillaGuzmán JC, Hernando S, Rodriguez-Vida A, González-Del-Alba A, Mellado B, Gonzalez-Billalabeitia E, Olmos D, Attard G and De Giorgi U: Plasma androgen receptor and docetaxel for metastatic castration-resistant prostate cancer. Eur Urol 75(3): 368-373, 2019. PMID: 30773204. DOI: 10.1016/j.eururo. 2018.09.049

33 Lavaud P, Gravis G, Foulon S, Joly F, Oudard S, Priou F, Latorzeff I, Mourey L, Soulié M, Delva R, Krakowski I, Laguerre B, Théodore C, Ferrero JM, Beuzeboc P, Habibian M, Rolland F, Deplanque G, Pouessel D, Zanetta S, Berdah JF, Dauba J, Baciuchka M, Platini C, Linassier C, Tubiana-Mathieu N, Machiels JP, Kouri CE, Ravaud A, Suc E, Eymard JC, Hasbini A, Bousquet G, Culine S, Boher JM, Tergemina-Clain G, Legoupil C and Fizazi K: Anticancer activity and tolerance of treatments received beyond progression in men treated upfront with androgen deprivation therapy with or without docetaxel for metastatic castration-naïve prostate cancer in the GETUG-AFU 15 Phase 3 trial. Eur Urol 73(5): 696-703, 2018. PMID: 29074061. DOI: 10.1016/j.eururo.2017.09.022

34 Loriot Y, Massard C, Gross-Goupil M, Di Palma M, Escudier B, Bossi A, Chauchereau A and Fizazi K: The interval from the last cycle of docetaxel-based chemotherapy to progression is associated with the efficacy of subsequent docetaxel in patients with prostate cancer. Eur J Cancer 46(10): 1770-1772, 2010. PMID: 20483588. DOI: 10.1016/j.ejca.2010.04.010

35 Heck MM, Thalgott M, Retz M, Wolf P, Maurer T, Nawroth R, Hatzichristodoulou G, Gschwend JE and Kübler H: Rational indication for docetaxel rechallenge in metastatic castrationresistant prostate cancer. BJU Int 110(11 Pt B): E635-E640, 2012. PMID: 22889368. DOI: 10.1111/j.1464-410X. 2012.11364.x

36 Di Lorenzo G, Pagliuca M, Perillo T, Benincasa A, Bosso D, De Placido $S$ and Buonerba C: Docetaxel rechallenge in a heavily pretreated patient with castration-resistant prostate cancer: a case report and review of literature. Medicine 
(Baltimore) 95(14): e2754, 2016. PMID: 27057826. DOI 10.1097/MD.0000000000002754

37 Oudard S, Kramer G, Caffo O, Creppy L, Loriot Y, Hansen S, Holmberg M, Rolland F, Machiels JP and Krainer M: Docetaxel rechallenge after an initial good response in patients with metastatic castration-resistant prostate cancer. BJU Int 115(5): 744-752, 2015. PMID: 24947139. DOI: 10.1111/bju.12845

38 Schweizer MT, Zhou XC, Wang H, Bassi S, Carducci MA, Eisenberger MA and Antonarakis ES: The influence of prior abiraterone treatment on the clinical activity of docetaxel in men with metastatic castration-resistant prostate cancer. Eur Urol 66(4): 646-652, 2014. PMID: 24491307. DOI: 10.1016/j.eururo. 2014.01 .018
39 Caffo O, Pappagallo G, Brugnara S, Caldara A, di Pasquale MC, Ferro A, Frisinghelli M, Murgia V, Russo LM, Soini B, Valduga F, Veccia A and Galligioni E: Multiple rechallenges for castration-resistant prostate cancer patients responding to firstline docetaxel: assessment of clinical outcomes and predictive factors. Urology 79(3): 644-649, 2012. PMID: 22386418. DOI: 10.1016/j.urology.2011.11.043
Received June 29, 2021

Revised August 28, 2021

Accepted September 6, 2021 